\title{
PEMBELAJARAN BIOLOGI MELALUI METODE EKSPERIMEN DENGAN LABORATORIUM RIIL DAN LABORATORIUM VIRTUIL DITINJAU DARI KEMAMPUAN BERFIKIR KRITIS DAN GAYABELAJAR SISWA
}

\author{
Ena Marsutji Setia Bakti ${ }^{1}$, Suparmi $^{2}$, Widha Sunarno ${ }^{3}$ \\ ${ }^{1}$ Program Pascasarjana, Universitas Sebelas Maret \\ Surakarta, Indonesia \\ enamarsujisetyob@yahoo.co.id \\ ${ }^{2}$ Pendidikan Saina, Program Pascasarjana, Universitas Sebelas Maret \\ Surakarta, Indonesia \\ suparmiuns@gmail.com \\ ${ }^{3}$ Pendidikan Saina, Program Pascasarjana, Univensitas Sebelas Maret \\ Surakarta, Indonesia \\ widhasunarno@gmail.com
}

\begin{abstract}
Abstrak
Penelitian ini bertujuan untuk mengetahui pengaruh penggunaan metode eksperimen melalui laboratorium riil dan virtuil, kemampuan berfikir kritis, gaya belajar, dan interaksinya terhadap prestasi belajar ranah kognitif dan afektif siswa. Penelitian dilaksanakan di SMP Negeri 1 Kecamatan Jetis semester 1 tahun pelajaran 2012-2013. Metode yang digunakan pada penelitian ini adalah metode eksperimen. Populasi pada penelitian ini adalah seluruh siswa kelas VIII. Sampel pada penelitian sebanyak 4 kelas diambil secara cluster random sampling. Pengumpulan data dengan menggunakan metode tes untuk prestasi kognitif dan kemampuan berfikir kritis. Metode angket untuk mengukur gaya belajar. Metode observasi untuk mengukur kognitif proses, sedangkan prestasi afektif menggunakan observasi dan angket. Analisis data menggunakan program PASW dan hipotesis dengan menggunakan anova 2x2x2. Hasil penelitian ini adalah: (1) ada pengaruh pengunaan metode eksperimen dengan lab riil dan lab virtuil terhadap prestasi kognitif dan afektif siswa; (2) ada pengaruh kemampuan berfikir kritis terhadap prestasi kognitif dan afektif siswa; (3) ada pengaruh gaya belajar terhadap prestasi kognitif dan afektif siswa; (4) ada interaksi penggunaan metode eksperimen dengan lab riil dan lab virtuil dengan kemampuan berfikir kritis terhadap prestasi kognitif dan afektif siswa; (5) tidak ada interaksi penggunaan metode eksperimen melalui lab riil dan virtuil dengan gaya belajar terhadap prestasi kognitif dan afektif siswa; (6) tidak ada interaksi penggunaan metode eksperimen melalui lab riil dan virtuil dengan kemampuan berfikir kritis dan gaya belajar terhadap prestasi kognitif dan afektif siswa; (7) tidak ada interaksi antara metode eksperimen melalui lab riil dan virtuil, kemampuan berfikir kritis, dan gaya belajar terhadap prestasi kognitif dan afektif siswa.
\end{abstract}

Kata Kunci: Metode Eksperimen, Laboratorium Riil, Laboratorium Virtuil, Kemampuan Berfikir Kritis, Gaya Belajar.

\section{Pendahuluan}

Dunia pendidikan merupakan suatu wadah untuk membangun generasi penerus yang akan melahirkan ilmu pengetahuan dan teknologi sebagai landasan peradaban manusia. Oleh karena itu kualitas peradaban manusia ditentukan oleh kualitas ilmu pengetahuan dan teknologi. Suatu negara yang memiliki peradaban yang maju karena penduduknya menguasai ilmu pengetahuan dan teknologi dengan sempurna.

Menurut Atherton (2005) menyebutkan bahwa asimilasi adalah "the process by which a person takes material into their mind from the environment, which may mean changing the evidence of their senses to make it fit" dan akomodasi adalah "the difference made to one's mind or concepts by the process of assimilation". Pembelajaran Biologi yang 
dilaksanakan adalah menggali kemampuan siswa dengan melaksanakan eksperimen secara kelompok, setelah selesai pembelajaran ini diharapkan siswa mampu memahami proses pencernaan manusia serta mengaplikasikannya dalam kehidupan sehari-hari. Dikemukakannya pula, bahwa belajar akan lebih berhasil apabila disesuaikan dengan tahap perkembangan kognitif peserta didik. Peserta didik hendaknya diberi kesempatan untuk melakukan eksperimen dengan obyek fisik, yang ditunjang oleh interaksi dengan teman sebaya dan dibantu oleh pertanyaan dari guru. Guru hendaknya banyak memberikan rangsangan kepada peserta didik agar mau berinteraksi dengan lingkungan secara aktif, mencari, dan menemukan berbagai hal dari lingkungan.

Biologi merupakan sebagai salah satu mata pelajaran yang terkait erat dengan sains dan teknologi yang memegang peranan yang sangat penting dalam mewujudkan sumber daya manusia yang dapat menguasai teknologi yang dibutuhkan khususnya di era globalisasi. Dengan penguasaan teknologi yang tinggi melalui pembelajaran biologi maka bangsa Indonesia akan mampu bersaing dengan bangsa lain. Selain itu dalam lingkup yang lebih kecil yakni sekolah, keberhasilan pembelajaran sains merupakan wujud keterlaksanaan kurikulum.

SMP Negeri 1 Kecamatan Jetis Ponorogo yang berstatus RSBI menuntut kualitas lulusan yang semakin meningkat, maka kualitas proses pembelajaran juga harus terus ditingkatkan. Materi sistem pencernaan pada manusia yang dipelajari siswa kelas VIII pada semester I penting bagi siswa, karena peristiwa pencernaan tidak bisa diamati secara langsung dan berkaitan dengan kehidupan sehari-hari atau kehidupan nyata. Misalnya ketika siswa memilih jenis makanan sehat dan bergizi, serta cara menjaga kesehatan organ pencernaan yang berkaitan dengan konsep proses pencernaan secara mekanik dan kimia. Sehingga dalam mempelajari materi sistem pencernaan manusia siswa dituntut untuk mengetahui berbagai hal tentang pencernaan pada manusia, diantaranya adalah macam-macam gizi yang diperlukan manusia, kandungan gizi dalam bahan makanan, alat-alat pencernaan, dan jenis-jenis enzim. Kemudian fungsi masing-masing zat makanan dan enzim serta alat-alat pencernaan. Dengan penguasaan konsep-konsep tersebut, maka siswa akan memiliki kecakapan dalam menyelesaikan masalah yang dihadapi tentang jenis makanan, fungsi makanan, proses pencernaan makanan, dan cara menjaga kesehatan organ-organ pencernaan.

Kenyataan di lapangan materi sistem pencernaan pada manusia dirasakan sulit bagi siswa. Siswa masih banyak yang kurang bisa memahami dalam menentukan jenis gizi yang terkandung dalam bahan makanan, misalnya dalam menentukan karbohidrat, protein, dan lemak. Selain itu siswa terkadang masih belum bisa menjelaskan perbedaan pencernaan makanan secara mekanik dan kimia yang berkaitan dengan fungsi alat pencernaan. Hal itu diperoleh dari hasil observasi di SMP N 1 Kecamatan Jetis.

Penelitian ini bertujuan untuk mengetahui adanya (1) pengaruh penggunaan metode eksperimen melalui laboratorium riil dan virtuil terhadap prestasi belajar siswa; (2) pengaruh kemampuan berfikir kritis tinggi dan rendah terhadap prestasi belajar siswa; (3) pengaruh gaya belajar visual dan kinestetik terhadap prestasi belajar siswa; (4) interaksi antara metode eksperimen melalui laboratorium riil dan virtuil dengan kemampuan berfikir kritis siswa terhadap prestasi belajar siswa; (5) interaksi antara metode eksperimen melalui laboratorium riil dan virtuil dengan gaya belajar siswa terhadap prestasi belajar siswa; (6) interaksi kemampuan berfikir kritis dengan gaya belajar siswa terhadap prestasi belajar siswa; (7) interaksi antara metode eksperimen melalui laboratorium riil dan virtuil dengan kemampuan berfikir kritis serta gaya belajar terhadap prestasi belajar siswa.

\section{Metode Penelitian}

Penelitian ini dilakukan di SMP Negeri 1 Kecamatan Jetis. Tahap persiapan, meliputi: pengajuan judul tesis, pembuatan proposal, dan perijinan yang dimulai bulan Maret 2012 sampai bulan September 2012. Kemudian pada tahap pelaksanaan, terdiri dari: penyusunan instrumen, validasi, uji coba, dan pengambilan data mulai bulan Nopember 2012. Pada analisis data dan penyusunan tesis dimulai pada bulan Desember 2012. Sejalan dengan masalah dan tujuan yang ada sehingga penelitian ini dilaksanakan dengan menerapkan metode 
penelitian experimental. Sumber data yang digunakan merupakan sumber data primer karena penelitian memperoleh data langsung dari subjek penelitian.

Pada penelitian ini populasi yang diteliti adalah siswa kelas VIII semester 1 SMP N 1 Kecamatan Jetis tahun pelajaran 2012/2013 yang berjumlah 4 kelas dengan 105 siswa. Pengambilan sampel menggunakan "Cluster Random Sampling”.

Teknik pengambilan data dilakukan dengan metode tes, observasi, angket, dan dokumentasi. Data prestasi belajar kognitif diperoleh dari hasil tes kepada siswa setelah selesai pembelajaran. Pada tes kemampuan berfikir kritis dan angket gaya belajar diperoleh sebelum proses pembelajaran, bertujuan untuk mengetahui tingkat kemampuan berfikir kritis dan karakteristik gaya belajar yang dimiliki siswa. Metode observasi dan dokumentasi diperoleh pada saat proses pembelajaran dan praktikum berlangsung. Metode observasi dan angket dilakukan untuk mengambil data prestasi afektif.

Uji validitas pada tes prestasi kognitif dan tes kemampuan berfikir kritis dilakukan untuk mengetahui alat evaluasi. Hasil uji coba dihitung daya beda soal, indeks kesukaran, validitas, dan reliabilitas. Angket gaya belajar dan angket afektif dihitung validitas dan reliabilitas.

Teknik analisis data pada penelitian ini terdiri dari uji prasyarat dan uji hipotesis. Pada uji prasyarat meliputi uji normalitas dan uji homogenitas. Uji normalitas menggunakan uji Kolmogorov Smirnov, sedangkan uji homogenitas dengan uji levene's test. Pada uji hipotesis data penelitian menggunakan uji anava Tests of Between-Subjects Effects.

\section{Hasil Penelitian dan Pembahasan}

Berdasarkan uji normalitas dan homogenitas data untuk nilai kognitif dan afektif menunjukkan data terdistribusi normal dan homogen, selanjutnya data dianalisa melalui (Anava) tiga jalan. Hasil uji disajikan pada Tabel 1.
Tabel 1. Hasil Uji Anava Prestasi Kognitif dan Afektif

\begin{tabular}{lrr}
\hline \multicolumn{1}{c}{ Analisis } & \multicolumn{2}{c}{$p$-value } \\
\cline { 2 - 3 } & Kognitif & Afektif \\
\hline Media & 0.002 & 0.046 \\
Kemampuan Befikir Kritis & 0.000 & 0.000 \\
Gaya Belajar & 0.045 & 0.006 \\
Media*Kemampuan Berfikir & 0.030 & 0.026 \\
Kritis & 0.198 & 0.509 \\
Media*Gaya Belajar & 0.748 & 0.402 \\
Kemampuan Berfikir Kritis*Gaya & & \\
Belajar & 0.092 & 0.404 \\
Media*Kemampuan Berfikir & & \\
Kritis*Gaya Belajar & & \\
\hline
\end{tabular}

1. Pengaruh penggunaan metode eksperimen dengan laboratorium riil dan laboratorium virtuil terhadap prestasi kognitif dan afektif siswa.

Berdasarkan hasil uji General Linier Model diperoleh $P$-value prestasi belajar pada aspek kognitif dan afektif masing-masing sebesar 0,002 dan 0,046. Nilai $P$-value $<$ taraf signifikansi $5 \%(\alpha=0,05)$ hipotesis ditolak, artinya ada pengaruh penggunaan metode eksperimen melalui laboratorium riil dan laboratorium virtuil terhadap prestasi belajar pada aspek kognitif dan afektif. Pada hasil uji lanjut memberikan informasi bahwa melalui laboratorium riil hasil mean prestasi kognitif dan afektif lebih besar dibandingkan dengan mean pada pembelajaran melalui laboratorium virtuil. Hal ini menunjukkan bahwa metode eksperimen melalui laboratorium riil lebih baik pengaruhnya dibandingkan dengan metode eksperimen melalui laboratorium virtuil terhadap penguasaan konsep sistem pencernaan pada manusia.

Pada proses belajar mengajar dikelas yang menerapkan metode eksperimen melalui laboratorium virtuil, siswa secara berkelompok melakukan praktikum melalui media komputer yang menyajikan praktikum tentang konsep sistem pencernaan pada manusia. Siswa mengamati dan mencatat hasil praktikum pada lembar kerja yang telah disiapkan oleh guru. Siswa mendiskusikan hasil praktikum dengan kelompoknya untuk membuat kesimpulan. Pada akhir pembelajaran seluruh kelompok mempresentasikan hasil praktikum.

Proses pembelajaran pada metode eksperimen melalui laboratorium riil, siswa secara langsung melakukan praktikum tentang 
konsep sistem pencernaan pada manusia sesuai prosedur yang ada pada LKS. Siswa mendata dan mendiskusikan hasil eksperimennya dengan kelompoknya masing-masing untuk membuat kesimpulan. Pada akhir pembelajaran seluruh kelompok mempresentasikan hasil praktikum.

Pada proses pembelajaran dengan laboratorium virtuil, banyak siswa yang kurang memahami tujuan yang harus dicapai karena hanya main tombol saja. Pada saat melakukan praktikum adanya kesalahan menyusun data sehingga menyebabkan kurang valid pada hasil praktikum. Hal ini menyebabkan siswa kurang maksimal dalam melakukan praktikum. Materi sistem pencernaan pada manusia merupakan materi yang tidak bisa langsung diamati yang memerlukan eksperimen dan banyak menggunakan aplikasi dalam kehidupan seharihari. Seperti halnya proses masuknya makanan ke organ-organ pencernaan, hasil dari karbohidrat, protein, lemak, dan vitamin, organorgan yang bekerja saat memproses makanan dan sebagainya.

Pada proses laboratorium riil siswa melakukan proses praktikum secara langsung sehingga siswa mengetahui letak kesalahan praktikum dan siswa dapat memperbaiki kesalahan tersebut. Data yang diperoleh lebih terkonsep dalam menarik kesimpulan. Pertanyaan yang sudah tersedia dalam LKS sangat membantu siswa untuk menemukan informasi tentang materi sistem pencernaan pada manusia. Pada laboratorium virtuil, siswa cenderung merasa bingung dalam menarik kesimpulan. Siswa yang belajar menggunakan laboratorium riil memperoleh mean prestasi belajar lebih baik dibanding dengan menggunakan media laboratorium virtuil.

Pada penelitian ini sejalan dengan penelitian yang dilakukan Avi Hofstein (2003) disimpulkan bahwa pembelajaran yang berbasis laboratorium telah menunjukkan keefektifan dalam pembelajaran sains. Kegiatan yang dilakukan di laboratorium mampu mengembangkan dan memperjelas hal-hal yang bersifat abstrak menjadi hal yang nyata. Penelitian ini juga sejalan dengan yang dilakukan oleh Slavko Kocijancic and Colm O'sullivan (2004) disimpulkan bahwa menggunakan eksperimen nyata hasilnya lebih baik dari pada laboratorium virtuil dalam mengajar sains di University of Ljubljana, Faculty of Education Kardejev.

2. Pengaruh kemampuan berfikir kritis terhadap prestasi kognitif dan afektif siswa.

Berdasarkan hasil uji General Linier Model diperoleh $P$-value prestasi belajar aspek kognitif dan afektif mempunyai hasil yang signifikan yaitu 0,000 dan 0,000 . Nilai $P$ value $<$ taraf signifikansi $5 \%(\alpha=0,05)$ hipotesis ditolak, artinya ada pengaruh kemampuan berfikir kritis terhadap prestasi belajar siswa kognitif dan afektif. Pada penelitian ini, kemampuan berfikir kritis siswa tinggi dan rendah memberikan pengaruh yang signifikan terhadap prestasi belajar kognitif dan afektif. Hal ini berarti bahwa dalam proses pembelajaran faktor kemampuan berfikir kritis siswa menunjang keberhasilan dalam prestasi siswa khususnya materi sistem pencernaan pada manusia. Tingkat kemampuan berfikir kritis siswa pada penelitian ini diketahui memberikan efek berbeda terhadap pencapaian prestasi belajar biologi baik kognitif maupun afektif. Berdasarkan perbandingan nilai mean prestasi kognitif dan afektif memberikan informasi bagi siswa yang memiliki tingkat kemampuan berfikir kritis tinggi mendapatkan mean prestasi lebih tinggi dari siswa yang memiliki tingkat kemampuan berfikir kritis rendah.

Kemampuan berfikir kritis merupakan suatu kemampuan yang dimiliki individu untuk melihat dan memecahkan masalah yang ditandai dengan sifat-sifat dan bakat kritis yaitu mempunyai rasa ingin tahu yang tinggi imajinatif dan selalu tertantang oleh kemajemukan, berani mengambil resiko, dan mempunyai sifat yang tak kalah adalah selalu menghargai hak-hak orang lain, arahan bahkan bimbingan orang lain. Siswa yang mempunyai kemampuan berfikir kritis tinggi mampu menyimpulkan dari apa yang diketahuinya, dan mengetahui cara memanfaatkan informasi untuk memecahkan masalah, dan mencari berbagai sumber. Siswa yang mempunyai kemampuan berfikir kritis rendah cenderung pasif dalam mencari informasi yang dikaitkan dengan materi sistem pencernaan pada manusia. Disimpulkan siswa yang mempunyai kemampuan berfikir kritis tinggi mampu menyelesaikan tes kognitif lebih baik daripada siswa yang mempunyai kemampuan berfikir kritis rendah. 
Pada prestasi afektif terlihat pada saat proses praktikum dan diskusi. Siswa yang mempunyai kemampuan berfikir kritis tinggi bersifat netral, obyektif, dan tidak bias. Siswa yang mempunyai berfikir kritis tinggi dapat menunjukkan kekeliruan atau alasan-alasan yang kurang tepat dengan selalu menggali informasi baik dari guru maupun dari buku. Pada saat berdiskusi siswa yang mempunyai berfikir kritis tinggi dapat memberikan penjelasan sederhana, menyimpulkan, memberikan penjelasan lanjut, dan mengatur strategi tentang konsep materi sistem pencernaan pada manusia. Siswa yang mempunyai kemampuan berfikir kritis rendah, mereka terbantu dengan adanya LKS sehingga proses penarikan kesimpulan dapat sesuai dengan yang diharapkan. Hal ini sejalan dengan penelitian yang dilakukan Cheryl Perkins dan Elizabeth Murphy (2007) disimpulkan bahwa keterlibatan siswa yang mempunyai berfikir kritis tinggi dalam proses diskusi sangat efektif dan lebih aktif dalam mengungkapkan pendapatnya. Berdasarkan uraian di atas dapat disimpulkan bahwa siswa yang mempunyai kemampuan berfikir kritis tinggi memperoleh mean prestasi afektif lebih tinggi dibanding dengan siswa yang mempunyai kemampuan berfikir kritis rendah.

3. Pengaruh gaya belajar terhadap prestasi kognitif dan afektif siswa.

Berdasarkan hasil uji General Linier Model diperoleh $P$-value prestasi belajar baik pada aspek kognitif dan afektif mempunyai hasil yang signifikan yaitu 0,045 dan 0,006 . Nilai $P$-value $<$ taraf signifikansi 5\% $(\alpha=0,05)$ hipotesis ditolak, artinya ada pengaruh gaya belajar visual dan kinestetik terhadap prestasi belajar siswa. Berdasarkan perbandingan nilai mean prestasi kognitif dan afektif diperoleh informasi bahwa siswa dengan gaya belajar visual cenderung mendapatkan prestasi yang lebih tinggi dibandingkan dengan siswa yang memiliki gaya belajar kinestetik.

Karakteristik siswa yang mempunyai gaya belajar visual antara lain bicara agak cepat, mementingkan penampilan dalam berpakaian/presentasi, tidak mudah terganggu oleh keributan, mengingat yang dilihat dari pada yang didengar, lebih suka membaca dari pada dibacakan, pembaca cepat dan tekun, seringkali mengetahui yang harus dikatakan, tapi tidak pandai memilih kata-kata, lebih suka melakukan demonstrasi dari pada pidato, lebih suka musik dari pada seni, mempunyai masalah untuk mengingat instruksi verbal kecuali jika ditulis, dan seringkali minta bantuan orang untuk mengulanginya. Karakteristik siswa yang mempunyai gaya belajar kinestetik antara lain berbicara perlahan, penampilan rapi, tidak terlalu mudah terganggu dengan situasi keributan, belajar melalui memanipulasi dan praktek, menghafal dengan cara berjalan dan melihat, menggunakan jari sebagai petunjuk ketika membaca, merasa kesulitan untuk menulis tetapi hebat dalam bercerita, menyukai buku-buku dan mereka mencerminkan aksi dengan gerakan tubuh saat membaca, menyukai permainan yang menyibukkan, tidak dapat mengingat geografi, kecuali jika mereka memang pernah berada di tempat itu dan menyentuh orang untuk mendapatkan perhatian mereka menggunakan kata-kata yang mengandung aksi.

Pada mata pelajaran IPA terutama biologi lebih bersifat tidak bisa dilihat dan banyak sekali menggunakan simbol-simbol dan gambar. Siswa yang mempunyai gaya belajar visual tidak mengalami kesulitan dalam hal memahami pelajaran biologi terutama pada konsep sistem pencernaan pada manusia. Mereka lebih bisa berkonsentrasi walaupun dalam keadaan yang ramai. Siswa yang mempunyai gaya belajar kinestetik sangat kesulitan dalam memahami materi sistem pencernaan pada manusia, sehingga dalam pembelajarannya memerlukan media yang nyata. Siswa yang memiliki gaya belajar kinestetik cenderung kurang bisa berkonsentrasi karena mereka lebih aktif mencatat informasi yang diberikan oleh guru. Hal ini sejalan dengan penelitian yang dilakukan Ibrahim Yasar Kazu (2009) disimpulkan bahwa efek gaya belajar pada proses pembelajaran sangat berpengaruh terhadap prestasi belajar yang akan diperoleh. Siswa memiliki gaya belajar yang bermacam-macam, sehingga proses penerimaan informasi berlangsung cepat atau tidak tergantung dengan metode yang cocok untuk masing-masing gaya belajar. Berdasarkan uraian di atas dapat disimpulkan bahwa siswa yang mempunyai gaya belajar visual memperoleh prestasi belajar kognitif dan afektif 
lebih tinggi dibanding dengan siswa yang mempunyai gaya belajar kinestetik.

4. Interaksi penggunaan metode eksperimen dengan lab riil dan lab virtuil dengan kemampuan berfikir kritis terhadap prestasi kognitif dan afektif siswa.

Berdasarkan hasil uji General Linier Model diperoleh $P$-value prestasi belajar pada aspek kognitif dan afektif masing-masing sebesar 0,030 dan 0,026 . Nilai $P$-value $<$ taraf signifikansi $5 \%(\alpha=0,05)$ hipotesis ditolak, artinya ada interaksi metode eksperimen melalui laboratorium riil dan laboratorium virtuil dengan kemampuan berfikir kritis terhadap prestasi belajar pada aspek kognitif dan afektif.

Berdasarkan dari penggunaan media laboratorium riil dan virtuil, siswa yang mempunyai kemampuan berfikir kritis tinggi memperoleh nilai mean prestasi kognitif dan afektif lebih tinggi daripada siswa yang mempunyai kemampuan berfikir kritis rendah. Pembelajaran dengan metode eksperimen melalui laboratorium riil dan virtuil menuntut siswa lebih mandiri dan aktif. Dalam proses mengambil kesimpulan siswa berusaha menggali informasi sebanyak-banyaknya baik dari buku ataupun dari guru. Siswa yang mempunyai kemampuan berfikir kritis tinggi dapat mengembangkan informasi yang sudah ada untuk memecahkan suatu masalah, seperti halnya menyelesaikan tes atau tugas dari guru. Hal ini dapat dilihat pada perbandingan nilai mean prestasi kognitif dan afektif, pada penggunaan laboratorium riil dan virtuil pada siswa yang mempunyai kemampuan berfikir kritis tinggi memperoleh prestasi kognitif dan afektif lebih tinggi dibanding siswa yang mempunyai kemampuan berfikir kritis rendah.

Pada siswa yang mempunyai kemampuan berfikir kritis rendah dapat mengikuti pembelajaran biologi terutama materi sistem pencernaan pada manusia bila diajar dengan metode eksperimen melalui laboratorium riil. Media laboratorium riil memberi gambaran yang jelas tentang sistem pencernaan pada manusia. Hal ini terlihat pada saat siswa melakukan praktikum, siswa terlihat antuasias dan senang dalam melakukan praktikum sendiri. Pada pembelajaran metode eksperimen dengan laboratorium virtuil, siswa yang mempunyai kemampuan berfikir kritis rendah mengalami banyak kesulitan dalam mengoperasikan, memahami informasi yang diberikan pada komputer. Hal ini dapat dilihat pada hasil uji lanjut anava terjadi interaksi pada kelompok siswa yang kemampuan berfikir kritis rendah jika diberi metode laboratorium riil dibanding dengan siswa yang mempunyai kemampuan berfikir kritis rendah jika diberi laboratorium virtuil memberikan perbedaan yang signifikan terhadap prestasi kognitif maupun afektif. Perbandingan nilai mean pada prestasi kognitif dan afektif, siswa yang mempunyai kemampuan berfikir kritis rendah memperoleh prestasi belajar kognitif dan afektif lebih tinggi bila diberi metode eksperimen melalui laboratorium riil dibanding dengan media laboratorium virtuil.

Pada siswa yang mempunyai kemampuan berfikir kritis tinggi sama-sama dapat mengikuti pembelajaran dengan metode eksperimen melalui laboratorium riil dan virtuil. Hal ini dapat dilihat pada hasil lanjut anava post hoc dengen uji scheffe, interaksi pada kelompok tersebut tidak memberikan perbedaan yang signifikan terhadap prestasi kognitif maupun afektif.

5. Penggunaan metode eksperimen melalui laboratorium riil dan virtuil dengan gaya belajar terhadap prestasi kognitif dan afektif siswa.

Berdasarkan hasil uji General Linier Model diperoleh $P$-value prestasi belajar pada aspek kognitif dan afektif masing-masing sebesar 0,198 dan 0,509. Nilai $P$-value $>$ taraf signifikansi 5\% $(\alpha=0,05)$ hipotesis diterima, artinya tidak ada interaksi antara metode eksperimen melalui laboratorium riil dan laboratorium virtuil dengan gaya belajar visual dan kinestetik terhadap prestasi belajar kognitif dan afektif.

Karekteristik siswa yang mempunyai gaya belajar kinestetik yaitu senang dengan halhal yang bersifat nyata. Pada metode eksperimen melalui laboratorium riil, siswa dengan gaya belajar kinestetik dapat mengikuti pembelajaran dengan baik. Hal ini terlihat bahwa siswa dengan gaya belajar kinestetik dapat mengalihkan keaktifannya dengan cara melakukan praktikum. Siswa dengan gaya belajar visual lebih dapat memahami gambargambar yang tersajikan pada komputer. Siswa dengan gaya belajar visual dan kinestetik bila diajar dengan metode eksperimen melalui 
laboratorium riil dan virtuil memperoleh perbedaan prestasi kognitif dan afektif yang tidak signifikan.

Kit Logan and Pete Thomas (2008) meneliti tentang gaya belajar siswa. Gaya belajar siswa dapat membantu siswa dalam belajar, dengan mengenal gaya belajar yang dimiliki siswa guru akan lebih mudah menggunakan metode dan media yang cocok untuk pembelajaran. Dalam penelitian ini, gaya belajar dijadikan faktor yang penting untuk mengunakan media yang dapat mempermudah siswa untuk belajar sesuai dengan gaya belajar dimilikinya.

Sehingga dapat disimpulkan bahwa tidak terjadi interaksi antara metode eksperimen melalui laboratorium riil dan virtuil dengan gaya belajar siswa. Artinya gaya belajar (visual dan kinestetik) dan penggunaan laboratorium riil dan virtuil mempunyai pengaruh sendirisendiri terhadap prestasi belajar biologi pada materi sistem pencernaan manusia. Hal ini dimungkinkan karena banyak faktor yang dapat mempengaruhi proses pencapaian prestasi belajar baik dalam maupun luar diri siswa diluar faktor metode pembelajaran, gaya belajar siswa yang digunakan dalam penelitian ini, serta masih banyak keterbatasan dalam penelitian ini sehingga tidak dapat mengontrol faktor-faktor tersebut di luar kegiatan belajar mengajar.

6. Interaksi penggunaan metode eksperimen melalui laboratorium riil dan virtuil dengan kemampuan berfikir kritis dan gaya belajar terhadap prestasi kognitif dan afektif siswa.

Berdasarkan hasil uji General Linier Model diperoleh P-value prestasi belajar kognitif dan afektif masing-masing sebesar 0,748 dan 0,402 . Nilai $P$-value $>$ taraf signifikansi $5 \%(\alpha=0,05)$ hipotesis diterima, artinya tidak ada interaksi kemampuan berfikir kritis dengan gaya belajar terhadap prestasi belajar siswa pada aspek kognitif dan afektif. Berdasarkan hasil analisis siswa yang mempunyai gaya belajar visual atau kinestetik dan siswa yang mempunyai kemampuan berfikir kritis tinggi atau rendah memperoleh prestasi belajar yang hampir sama.

Prestasi belajar pada aspek kognitif dan afektif, siswa yang mempunyai kemampuan berfikir kritis tinggi dan gaya belajar visual lebih mampu memahami dan menyimpulkan informasi yang bersifat abstrak terutama pada pelajaran biologi materi sistem pencernaan pada manusia. Siswa yang mempunyai gaya belajar kinestetik dan kemampuan berfikir kritis tinggi juga dapat menutupi kelemahan dengan cara mencari informasi sebanyak-banyaknya.

Pada proses pembelajaran dengan kondisi dan situasi yang berbeda pula siswa lebih senang dan tidak jenuh dengan pelajaran biologi yang banyak memerlukan hafalan. Sehingga dapat disimpulkan bahwa, tidak ada interaksi antara kemampuan berfikir kritis dengan gaya belajar terhadap prestasi belajar pokok materi sistem pencernaan pada manusia. Artinya tingkat kemampuan berfikir kritis dan gaya belajar siswa mempunyai pengaruh yang tidak signifikan terhadap prestasi belajar biologi. Hal ini dimungkinkan karena kemampuan berfikir kritis dan gaya belajar yang dapat mempengaruhi proses pencapaian prestasi belajar.

7. Interaksi antara metode eksperimen melalui laboratorium riil dan virtuil, kemampuan berfikir kritis, dan gaya belajar terhadap prestasi kognitif dan afektif siswa.

Berdasarkan hasil uji General Linier Model diperoleh $P$-value prestasi belajar pada aspek kognitifdan afektif masing-masing sebesar 0,092 dan 0,404 . Nilai $P$-value $>$ taraf signifikansi 5\% $(\alpha=0,05)$ hipotesis diterima, artinya tidak ada interaksi antara metode eksperimen melalui laboratorium riil dan laboratorium virtuil dengan kemampuan berfikir kritis (tinggi dan rendah) dan gaya belajar (visual dan kinestetik) terhadap prestasi belajar kognitif dan afektif.

Siswa yang mempunyai kemampuan berfikir kritis rendah dan gaya belajar kinestetik lebih cocok bila diajar dengan metode eksperimen melalui laboratorium riil. Siswa pada kelompok tersebut lebih senang melakukan secara langsung daripada melalui laboratorium virtuil. Siswa yang mempunyai kemampuan berfikir kritis rendah dan gaya belajar visual juga dapat memahami gambargambar yang telah tersaji pada media komputer. Pada saat proses pembelajaran baik menggunakan laboratorium riil dan virtuil terjadi kerjasama yang baik antara kelompok siswa yang mampunyai kemampuan berfikir 
kritis (tinggi dan rendah) dan gaya belajar (visual dan kinestetik).

Dapat disimpulkan bahwa tidak terjadi interaksi antara metode eksperimen melalui laboratorium riil dan virtuil, kemampuan berfikir kritis dan gaya belajar terhadap prestasi belajar biologi pada materi sistem pencernaan pada manusia. Artinya tingkat kemampuan berfikir kritis, gaya belajar dan penggunaan metode eksperimen melalui laboratorium riil dan laboratorium virtuil mempunyai pengaruh sendiri-sendiri terhadap prestasi belajar biologi pada materi sistem pencernaan pada manusia. Hal ini dimungkinkan karena banyak faktor yang dapat mempengaruhi proses pencapaian prestasi belajar (kognitif dan afektif) baik dalam maupun luar diri siswa diluar faktor media pembelajaran, kemampuan berfikir kritis dan gaya belajar siswa yang digunakan dalam penelitian ini, serta masih banyak keterbatasan dalam penelitian ini sehingga peneliti tidak dapat mengontrol faktor-faktor tersebut di luar kegiatan belajar mengajar.

\section{Kesimpulan dan Rekomendasi}

Berdasarkan hasil analisis dan pengujian hipotesis yang telah dipaparkan, dapat disimpulkan: (1) penggunaan metode eksperimen melalui laboratorium riil dan virtuil memberikan adanya pengaruh, mean media laboratorium riil lebih besar dibandingkan laboratorium virtual; (2) kemampuan berfikir kritis siswa tinggi dan rendah memberikan pengaruh yang signifikan terhadap prestasi belajar kognitif dan afektif; (3) siswa yang mempunyai gaya belajar visual lebih memberikan pengaruh yang signifikan terhadap prestasi belajar kognitif dan afektif; (4) interaksi siswa yang mempunyai tingkat kemampuan berfikir kritis dengan metode eksperimen melalui laboratorium riil dan virtuil termodifikasi mempunyai pengaruh yang signifikan terhadap prestasi belajar kognitif dan afektif; (5) penggunaan metode eksperimen melalui laboratorium riil dan virtuil dengan gaya belajar mempunyai pengaruh yang tidak signifikan terhadap prestasi belajar kognitif dan afektif; (6) interaksi antara tingkat kemampuan berfikir kritis dengan gaya belajar mempunyai pengaruh yang tidak signifikan terhadap prestasi belajar aspek kognitif dan afektif; (7) penggunaan metode eksperimen melalui laboratorium riil dan virtuil dengan kemampuan berfikir kritis dan gaya belajar mempunyai pengaruh sendiri-sendiri terhadap prestasi belajar kognitif dan afektif.

Penggunaan metode eksperimen melalui laboratorium riil dan virtuil, hendaknya dilakukan dengan persiapan yang matang, sehingga pembelajaran dapat berjalan lancar sesuai dengan rencana. Beberapa hal yang perlu disiapkan dalam penggunaan metode eksperimen melalui laboratorium riil dan virtuil antara lain: 1.) menyiapkan dan mengecek alat dan bahan untuk melakukan praktikum, 2.) menyiapkan LKS dengan sintaks berdasarkan metode eksperimen dan sumber informasi lain yang dapat mempermudah siswa dalam memahami konsep.

Perlu dilakukan penelitian tentang faktorfaktor lain yang berpengaruh terhadap prestasi belajar, sehingga dapat menambah pengetahuan guru dalam upaya meningkatkan prestasi belajar siswa.

Hasil penelitian ini dapat digunakan sebagai acuan untuk penelitian-penelitian berikutnya yang sejenis dan hasil penelitian ini diharapkan dapat memberikan kontribusi bagi perkembangan ilmu pengetahuan khususnya pada materi sistem pencernaan manusia.

\section{Daftar Pustaka}

Atherton, J. (2005). Language, Idoelogis and Practices. New York: Palgrave: MacMillan.

Georgiou, J.K. Dimitropoulos, and A. Manitsaris. (2007). A Virtual Reality Laboratory for Distance Education in Chemistry. Greece: the Aristotle University of Thessaloniki. International Journal of Social and Human Sciences 1, 2007.

John K. Gilbert dan Miriam Reiner. (2000). Haifa, Israel: School of Education, The University of Reading, UK. Department of Education in Science and Technology,Technion,. INT. J. SCI. EDUC., 2000, VOL. 22, NO. 3, 265- 283.

Kit Logan and Pete Thomas. (2002). Learning Styles in Distance Education Students Learning to Program. Brunel: Department of Computing Open University. 
ISSN: 2252-7893, Vol 2, No 32013 (hal 338-246)

http://jurnal.fkip.uns.ac.id/index.php/sains

Mujijono. (2005). Pengaruh Penerapan Laboratorium Riil dan Virtuil Pada Pembelajaran Siswa Ditinjau Kreativitas Siswa. Tesis. Surakarta: Universitas Sebelas Maret Surakarta.

Mulyasa, E. (2008). Praktik Penelitian Tindakan Kelas. Bandung: Remaja Rosdakarya.

Paul Suparno. (2007). Teori Perkembangan Kognitif Jean Piaget. Jogjakarta. Kanisius.

Slavko KOCIJANCIC and Colm O'SULLIVAN. (2004). Real or Virtual Laboratories in Science Teaching -is this Actually a Dilemma? Slovenia: University of Ljubljana, Faculty of Education Kardejeva pl. 16, SI-1000 Ljubljana, Journal in Education, 2004, Vol. 3, No. 2, 239-250.

Sri Rumini, dkk. (1995). Psikologi Pendidikan. Yogyakarta: Unit Percetakan dan Penerbitan (UPP) UNY. 